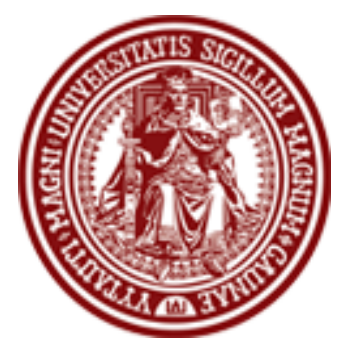

DE DE GRUYTER OPEN

\section{BALTIC JOURNAL OF LAW \& POLITICS}

A Journal of Vytautas Magnus University

VOLUME 9, NUMBER 2 (2016)

ISSN 2029-0454

\title{
BARAK'S PURPOSIVE INTERPRETATION IN LAW AS A PATTERN OF CONSTITUTIONAL INTERPRETATIVE FIDELITY
}

\author{
Tanasije Marinković \\ Associate Professor; Ph.D. \\ University of Belgrade, Faculty of Law (Serbia) \\ Contact information \\ Address: Bulevar kralja Aleksandra 67, 11000 Belgrade, Serbia \\ Phone: +38163308 869 \\ E-mail address: tanasije.marinkovic@ius.bg.ac.rs
}

Received: November 21, 2016; reviews: 2; accepted: December 19, 2016.

\section{ABSTRACT}

Political jurisprudence points out that constitutional court judges sometimes act like political actors, and that their decisions are a function of strategic and ideological as much as legal considerations. Consequently, the proper role of the courts, notably in exercising their review of constitutionality, has been one of the most debated issues in modern political and legal theory. Part of the controversy is also how to measure the interpretative fidelity of judges to the constitutional texts, or conversely, the level of their political engagement. This paper argues for the reconsideration of Aharon Barak's Purposive Interpretation in Law in that light. Barak's work was intended to provide, in the first place, judges and other lawyers with a sort of judicial philosophy - a holistic system of legal reasoning, applying both to the interpretation of will, contract, statute and constitution. Nevertheless, these conventions of legal reasoning, modified and readapted, could well be used also as heuristic tools by the academics in measuring the interpretative fidelity of judges to various sources of law. Accordingly, this paper clings closely to the presentation of Barak's precepts for the purposive interpretation of constitutions, by focusing on the notions of subjective and 
objective purpose in interpreting constitutions, and how the potential conflicts between these purposes are resolved.

\section{KEYWORDS}

Political jurisprudence, review of constitutionality, judicial self-restraint, judicial activism, purposive interpretation, subjective purpose, objective purpose 


\section{INTRODUCTION}

Courts are political agencies and judges are political actors. They decide cases not only on the basis of objective legal norms, but also their values and ideologies, as well as with an eye on the expectations of other political institutions. This is why judges should take their place with other political decision-makers, and be studied by both legal and political scholars. These are the principal tenets of political jurisprudence - political science oriented research on the attitudes and behavior of judges.

How can the judge's interpretative fidelity to law be evaluated. After all, constitutions and other legal sources are sometimes vague, inconsistent and contain gaps. The proper role of the courts, notably in wielding their power of judicial review, has been the subject of one of the central controversies in the modern political and legal science, confronting the supporters of judicial selfrestraint on one side and judicial activism on the other.

Aharon Barak's Purposive Interpretation in Law offers lawyers a sort of judicial philosophy - a holistic system of legal interpretation, equally applicable to the interpretation of will, contract, statute or constitution. Indeed, Barak envisaged his theory to serve legal practitioners, in the first place judges, to better actualize the purpose that the legal sources were designed to achieve. Nevertheless, it can well be used, with certain modifications and adaptations, as a heuristic tool by academics in measuring interpretative fidelity of judges to law.

This article argues for the reconsideration of Barak's work in that light - as a potential pattern for measuring judges' interpretative fidelity to constitutional texts, and conversely, the level of their political engagement. Equity among litigants, predictability, democracy and the rule of law are just some of the reasons why not only academics, but citizens and public opinion in general, should have some yardstick for that process. To that end, I look first at political jurisprudence, its sources and premises Then I examine briefly judicial self-restraint - the activism debate in the USA and I question whether it has relevance for the European context Lastly I present Barak's precepts for the purposive interpretation of constitutions, by focusing on the notions of subjective and objective purpose in interpreting constitutions, and how the potential conflicts between these purposes are resolved. 


\section{POLITICAL JURISPRUDENCE}

Political jurisprudence is a widely acknowledged term for most of the political science oriented research on the courts. It developed in the second half of the twentieth century in the USA as an extension of other doctrinal movements, namely sociological jurisprudence and legal realism. From the former, it derives a conception of the law as an integral part of the social system and an interest in the impact of legal arrangements on the distribution of power in a given society; from the latter it borrows a concern for the behavior of judges and an understanding that judges make, rather than simply discover law. ${ }^{1}$

Consequently, political jurisprudence relies on the premise that courts are political agencies and that judges are political actors who take their place with the members of parliament, ministers, city councilmen and other public officials who make political decisions. ${ }^{2}$ It studies the attitudes of judges, environment of judicial decisions, and, above all, how judges make decisions. In that sense, it has been advanced that "judges decisions are a function of what they prefer to do, tempered by what they think they ought to do, but constrained by what they perceive is feasible to do". ${ }^{3}$ This definition summarizes three different models of judicial decision-making, each richly elaborated in the political and legal literature: attitudinal model, legal model and strategic model. ${ }^{4}$

These considerations come into sharp conflict with the traditional continental European understanding of the judiciary as "merely a secondary branch of the executive function and a separate 'power' only in the limited sense that the judicial action is performed by distinct agencies or persons". ${ }^{5}$ Following Montesquieu, it considers judges as mouthpieces of the law and inanimate beings who can moderate neither its force nor its rigour ("la bouche qui prononce les paroles de la Ioi"). ${ }^{6}$ Political jurisprudence labels these positions ideological, and denounces the whole web and myth of speciality and mystery that surrounds and supports the traditional perception of judicial power as null and void ("en quelque façon nulle"). This thesis is commonly buttressed with examples of landmark judgments from across the world, in which judges acted as a political power.

\footnotetext{
1 Martin Shapiro \& Alec Stone Sweet, On Law, Politics and Judicialization (Oxford and New York: Oxford University Press, 2002), 19-20.

2 Ibid., 4, 21.

3 James L. Gibson, "Judicial Institutions": 515-516; in: R. A. W. Rhodes, Sarah A. Binder, and Bert A. Rockman. The Oxford Handbook of Political Institutions (Oxford and New York: Oxford University Press, 2008).

${ }^{4}$ Cf. Keith E. Whittington, R. Daniel Kelemen, and Gregory A. Caldeira, eds., The Oxford Handbook of Law and Politics (Oxford and New York: Oxford University Press, 2010)

${ }^{5}$ Karl Loewenstein, Political Power and the Governmental Process (Chicago: The University of Chicago Press, 1957), 239.

6 Montesquieu, De l'Esprit des lois, I (Paris: Gallimard, 1995), 333 \& 337.
} 
The best known such case is certainly Marbury $v$. Madison in which the US Supreme Court asserted for itself the power to declare laws unconstitutional, and thus to refuse to enforce them. ${ }^{7}$ The Marbury controversy lay in the fact that the Court's authority to exercise judicial review did not exist in any provision of the Constitution nor any act of Congress. Responding to it, Thomas Jefferson, the US President at that time, argued against citing Marbury and proposed to have the decision denied to be law. ${ }^{8}$ Still, there had been cases before the federal and state courts in which this power had already been applied, ${ }^{9}$ proving that the whole idea was not essentially strange to the lawyers of the founding generation. ${ }^{10}$

An even more striking example, coming precisely from Montesquieu's homeland of France, reveals that the constitutional court singlehandedly extended its competences, at the expense of the President and the Parliament. In the decision Liberté d'association, known also as the French Marbury, the Conseil constitutionnel declared the Preamble of the 1958 Constitution, which referred to the 1789 Declaration of Rights of Man and Citizen, to be an integral part of the Constitution. ${ }^{11}$ It thereby introduced into the French constitutional system the substantive judicial review of constitutionality, given the fundamental character of rights, thus acquiring qualities of a genuine constitutional court. However, the travaux préparatoires clearly pointed to the contrary - that the Constitutiondrafters did not consider the Preamble to have binding force.

If the legitimacy of the judicial review of constitutionality can be vexing in countries in which it is not enshrined in the formal constitution, it can hardly be expected to be understood, let alone justified, in countries without any formal constitutional text. Surprising as it may be, the latter is the case with Israel, where the Knesset has never adopted a constitution. However, over time, it did enact eleven fundamental laws, coined as such because of their purpose to organize and limit public power; and, it specified that they could be amended only by an absolute majority, regardless of the fact that they had been voted by a simple minority. At first, the Supreme Court held that the subsequent Knessets were tied by this condition, despite the principle of lex posterior, expending this doctrine in its 1995

\footnotetext{
7 Marbury v. Madison, 5 U.S. 137 (1803).

8 John Brigham, "Judicial Review": 538; in: Kermit L. Hall, James W. Ely, Jr., and Joel B. Grossman, eds., The Oxford Companion to the Supreme Court of the United States (Oxford and New York: Oxford University Press, 2005).

9 William M. Wiecek, Liberty under Law - The Supreme Court in American Life (Baltimore and London: The Johns Hopkins University Press, 1990), 33.

10 Mark Tushnet, "The United States: Eclecticism in the Service of Pragmatism": 17; in: Jeffrey Goldsworthy, ed., Interpreting Constitutions - A Comparative Study (Oxford \& New York: Oxford University Press, 2006).

11 Décision no. 71-44 DC du 16 juillet 1971.
} 
judgment United Misrahi Bank Ltd. v. Migdal Village to include its power to conduct the review of validity of any laws that violate the fundamental laws. ${ }^{12}$

If political power is defined by decision-making which is, legally speaking, discretionary, that is, not bound by law, and which has a collective effect, then it has to be admitted that constitutional courts act sometimes politically. ${ }^{13}$ Being at the apex of the legal system, due to their power to strike down or uphold acts of other constitutional bodies, they enjoy a certain liberty in the interpretation both of the constitution and the acts which are the object of their control. Such liberty becomes arbitrariness when it is exercised without any interpretative fidelity to law, and, as witnessed by the aforementioned rulings, it can get to the point of being exercised even without a textual basis.

\section{JUDICIAL SELF-RESTRAINT V. JUDICIAL ACTIVISM}

Taking into account the examples of judicial politics referred to in the previous section, it comes as no surprise that the role of the courts, notably in wielding their power of review of constitutionality, has been the subject of one of the central controversies of modern American and European jurisprudence.

In the USA, the main actors of the debate are the supporters of judicial selfrestraint, on the one side, and judicial activism, on the other. Judicial self-restraint is a label covering a number of related ideas all pleading for the US Supreme Court to restrain its powers. In one account, the Court should not "decide a dispute if there is no concrete injury to be relieved by a judicial decision [...], if the conflict between parties is a matter of contingency rather than actuality $[\ldots]$, if the real conflict has already passed [...], and if there is no genuine case presented in an adversary proceeding, but a mere request for an opinion on a legal question". ${ }^{14}$ In another, less technical account the plea for judicial self-restraint counsels the justices not to confuse their own views of right and wrong with the words of the Constitution, understood in their original meaning. ${ }^{15}$ However, the most straightforward usage of judicial self-restraint is the one of 'deference' to republican authority. According to this doctrine "most constitutional clauses permit a range of meaning over which reasonable people might differ. Thus, when a justice considers a law that fits within this range of reasonable interpretation, respect for republican authority requires that he or she should 'defer' to the legislature's assessment of its

\footnotetext{
12 Norman Dorsen, Michel Rosenfeld, Andras Sajo, and Susanne Baer, Comparative Constitutionalism Cases and Materials (St. Paul, MN: Thomson West, 2003), 103-110.

${ }^{13}$ Cf. Charles Eisenmann, "La justice dans I'Etat"; in: Charles Leben, ed., Charles Eisenmann, Ecrits de théorie du droit, de droit constitutionnel et d'idées politiques (Paris: Edition Panthéon-Assas, 2002).

${ }_{14}$ Stanley C. Brubaker, "Judicial Self-Restraint": 542; in: Kermit L. Hall, James W. Ely, Jr., and Joel B. Grossman, eds., supra note 8.

15 Ibid.
} 
constitutionality. Only when the legislature has made 'a clear mistake', should the justices hold the whole law void". ${ }^{16}$ Finally, the most restraining account, anchored in the separation of powers argument, sees in the Constitution a system of separate and co-equal departments, and considers judicial review, which has no specific authorization in the Constitution, as contrary to the whole design. ${ }^{17}$

Judicial activists themselves differ on many points. However, to the most poignant charges they all reply in one voice: that the Constitution is law, that it is within the province of the courts to interpret and apply law and, accordingly, interpret and apply the Constitution. In fact, they further suggest that a refusal to look to the Constitution would decide the case in favor of the statute and against the Constitution. ${ }^{18}$

This dichotomy of judicial self-restraint v. activism was adopted in the European context unreflectively, ${ }^{19}$ just like many other concepts and typologies. In comparison to their US equivalent, constitutions on the European continent are clearly law, ${ }^{20}$ they are fairly new and regularly amended, ${ }^{21}$ and they generally opt for a centralized system of judicial review of legislative acts embodied in a specialized, constitutional court. ${ }^{22}$ With some exceptions, notably France, ${ }^{23}$ this type of control has never been seriously challenged among the European liberal democracies. ${ }^{24}$

Thus, the debate whether a given constitutional court is activist or not seems rather displaced in Europe. Either the constitutional court effectively exercises its constitutionally mandated authority to review legislative acts or it does not.

\footnotetext{
16 Ibid.: 543.

17 Martin Shapiro, Freedom of Speech: The Supreme Court and Judicial Review (Englewood Cliffs, New Jersey: Prentice-Hall, Inc., 1966), 6.

18 Ibid., 7.

19 Daniel Smilov, "The Character and Legitimacy of Constitutional Review: Eastern European Perspectives. A Review of: Wojciech Sadurski, ed., Constitutional Justice, East and West: Democratic Legitimacy and Constitutional Courts in Post-Comunist Europe in a Comparative Perspective (Kluwer Law International, The Hague-London-New York: 2003), 450 pp.; Radoslav Prochazka, Mission Accomplished: On Founding Constitutional Adjudication in Central Europe (Central European Univ. Press, Budapest New York: 2002), 358 pp.," International Journal of Constitutional Law 1 (2004): 180.

20 For instance, the US Constitution uses rather general terms to deal with issues of enduring importance, while the German Basic Law is an elaborate framework of rules, powers and principles, and includes many code-like provisions. Cf. Mark Tushnet, supra note 10, 17; Donald P. Kommers, "Germany: Balancing Rights and Duties": 167 \& 177; in: Jeffrey Goldsworthy, ed., Interpreting Constitutions - A comparative Study (Oxford and New York: Oxford University Press, 2006).

${ }^{21}$ Again, to compare the US Constitution and the German Basic Law, the former was adopted in 1787 and has been amended 27 times since then, while the latter was adopted in 1949, and has been amended no less than 60 times so far.

22 Only seven European countries do not have constitutional courts (Switzerland, Norway, Ireland, Denmark, Sweden, Greece and Estonia) and two do not have any kind of judicial review of constitutionality (United Kingdom and Netherlands). Cf. Michel Fromont, La justice constitutionnelle dans le monde (Paris: Dalloz, 1996), 13-26.

${ }^{23}$ Alec Stone Sweet, "The Politics of Constitutional Review in France and Europe," International Journal of Constitutional Law 1 (2007): 73.

24 "In contrast to the United States and Canada, European constitutional adjudication has not developed a tradition of self-doubt, agonizing over legitimacy, or 'exercising the utmost care' whenever 'breaking new ground' in constitutional matters" (Wojcicech Sadurski, Rights Before Courts - A Study of Constitutional Courts in Postcommunist States of Central and Eastern Europe (Dordrecht: Springer, 2005), XIII).
} 
However, in all of three possible outcomes - when it refuses its jurisdiction, when it accepts its jurisdiction and validates or invalidates the disputed legislation - we can distinguish situations in which the court, rather than using a more straightforward answer, grounds its decision in very abstract and vague legal terms, the specific articulation of which splits the epistemic community.

Only then - such is the claim of this article - can one speak of judicial activism, or better yet, judicial politics, in the European context. Such activism can be strong or weak, depending on whether the court's reasoning, be it constructivist or preservationist, opposes or supports the parliament's will. In other words, and contrary to conventional understanding, ${ }^{25}$ the constitutional court may act as a political agent both when it accepts and refuses its jurisdiction, and in the case of the former, when it upholds and overturns the contested legislation. The dividing line is whether it exercises its function with interpretative fidelity to the pertinent sources of the law or not.

\section{PURPOSIVE INTERPRETATION IN LAW}

The precise question is how to understand interpretative fidelity to constitutional texts. After all, constitutions are inevitably ambiguous, vague, inconsistent and incomplete. ${ }^{26}$ The question of appropriate canons of judicial reasoning is so complex that it would take a whole book just to go through various possibilities of interpretative fidelity that different authors have in mind, ${ }^{27}$ or to summarize interpretive approaches and methodologies of various constitutional judiciaries. ${ }^{28}$

Aharon Barak's Purposive Interpretation in Law is intended to provide judges and other lawyers with a sort of judicial philosophy - a holistic system of legal reasoning, applicable equally to the interpretation of will, contract, statute or constitution. It summarizes and assembles different conventions of judicial reasoning in one relatively coherent whole. While it is obvious that Barak envisaged his theory of purposive interpretation to serve legal practitioners, above all judges, it can just as well be used, with certain modifications and adaptations, as a heuristic tool for academics in measuring interpretative fidelity of judges to various sources of law. In this section I limit myself to the description of Barak's precepts for the purposive interpretation of constitutions. After a short introduction, I will

\footnotetext{
25 For instance, Sadurski's two criteria test for an inquiry into the judicial activism includes invalidation of a norm which is of importance for the political branches of power. Ibid., 96-97.

26 Jeffrey Goldsworthy, "Conclusions": 321; in: Jeffrey Goldsworthy, ed., Interpreting Constitutions - A comparative Study (Oxford \& New York: Oxford University Press, 2006).

27 Cf. Daniel Smilov, supra note 19: 185.

${ }^{28}$ Cf. Jeffrey Goldsworthy, ed., Interpreting Constitutions - A comparative Study (Oxford and New York: Oxford University Press, 2006).
} 
present the notions of subjective (4.1) and objective (4.2) purpose in interpreting constitutions, and how the ultimate purpose is formulated on their basis (4.3).

Barak's Purposive Interpretation in Law is complex. Its starting point is the rejection of the "free systems 'of interpretation' that allow an interpreter to give a text any meaning he or she desires". ${ }^{29}$ Barak considers that there is nothing interpretive about those systems which replace basic linguistic and jurisprudential principles with nihilism. Against that kind of thinking, Barak pleads for a purposive interpretation, whose goal is to achieve "the purpose that the legal text is designed to achieve".30

Purposive interpretation is based on three components: language, purpose, and discretion. Language determines the range of semantic possibilities within which the interpreter acts as he or she chooses the legal meaning of the text from different possibilities, explicit or implied. ${ }^{31}$ The purposive component is essential in the interpretation of a legal text. It implies "the values, goals, interests, policies, and aims that the text is designed to actualize". ${ }^{32}$ Finally, Barak recognizes the indispensability of interpretive discretion in determining the ultimate purpose of the norm: "It is the choice that purposive interpretation gives the judge from among a few interpretive possibilities, all of which are legal", in order "to formulate the purpose at the core of the text". ${ }^{33}$

\subsection{SUBJECTIVE PURPOSE IN INTERPRETING CONSTITUTIONS}

The establishment of the purpose, the core element of the interpretative process, entails two sets of considerations, subjective and objective, each of which is multilayered in itself. The subjective purpose constitutes the values, goals, interests, policies, aims, and function that the specific constitution maker sought to actualize. Generally speaking, "it is its psychobiological intent, not the intent of a reasonable person", which an interpreter learns "through the language of the text as a whole and the circumstances external to it, like the history of its creation". ${ }^{34}$ "Often, the information from different sources about the subjective purpose points in one clear direction, but sometimes the sources conflict. In those instances", Barak propounds, "the interpreter seeks the meaning that best realizes the intent of

\footnotetext{
29 Aharon Barak, Purposive Interpretation in Law, trans. Sari Bashi (Princeton and Oxford: Princeton University Press, 2005), 25.

30 Ibid., 88.

31 Ibid., 89.

32 Ibid.

33 Ibid., 91.

34 Ibid., 89.
} 
the author. The more credible the information, the more weight the interpreter should give it". ${ }^{35}$

The constitution-making context concerns the events that brought about the constitution and provide information about the intent of its founders. It includes: pre-enactment history (the reasons and factors that led to the constitution's passage, including reports of public committees), the constitutional assembly history (committee and plenum hearings and debates), and the post-enactment history (events taking place after the passage of the constitution that point to the intent at its core). ${ }^{36}$

Barak does not deny that things get more complicated in constitutional law, in general, when the author of a text is a multi-member body. Such is the case for a constitution adopted by members of a constitutional assembly. The author of the text is the abstract legal entity (the assembly). ${ }^{37}$ Nevertheless, "an interpreter should not seek the motivations that propelled the members of the legislative body to vote in favor of the statute but rather should focus on the general objectives they sought to achieve". ${ }^{38}$ Still, Barak admits that "interpreters sometimes reach the point where they realize that it is impossible to identify subjective intent of the authors, and that they should abandon the search. Such is the case in interpreting a referendum". ${ }^{39}$

\subsection{OBJECTIVE PURPOSE IN INTERPRETING CONSTITUTIONS}

The objective purposes of a constitution are "the values, goals, interests, policies, aims, and function that the text should actualize in a democracy". ${ }^{40}$ It is a legal construction which operates at different levels of abstraction. Accordingly, it does not express an actual, but rather a hypothetical intent. And it is not a psychobiological fact, nor does it reflect a particular historical event. ${ }^{41}$

\subsubsection{AUTHOR'S HYPOTHETICAL INTENT}

The first and lowest level of abstraction - "imaginative reconstruction" focuses on the authors of the text, inquiring into the values, objectives, designs, and function that the members of the constitutional assembly would have wanted to actualize had they been asked to resolve the legal question before the judge.

\footnotetext{
35 Ibid., 90

36 Ibid., 140.

37 Ibid., 132.

38 Ibid., 134

39 Ibid., 130

${ }^{40}$ Ibid., 90.

41 Ibid., 148.
} 
"This is the hypothetical-individual intent. It does not reflect the 'real' intent of a specific author. It reflects a conjecture as to the intent he or she would have had". ${ }^{42}$ The interpreter puts himself or herself in the constitution maker's shoes - in the historical reality of the time the text was created - looking for the purpose that it would have held, had the present issue emerged. This reconstruction is not without challenges as the constitution maker may not have been able to give an answer, had the question in fact been posed at the time of writing, because its spiritual world is different from the one that produced the unresolved interpretive issue. Still, the interpreter, Barak insists, "uses his or her imagination as best he or she can". 43

An interpreter learns the constitution maker's hypothetical intent and the objective purpose of the constitutional text by studying the history and environment that created it. As Barak puts it: "History should not control us, but neither should we try to escape it. In addition to examining history for authorial intent, in the context of subjective purpose, we examine history to see what it can teach us about the role the text should play in the present". ${ }^{44}$ Accordingly, the interpreter has to take into account: "the fundamental social and cultural assumptions framing the text; the social and intellectual history in which the text operates; the culture and the intellectual conventions surrounding the text's conception; and the 'national way of life'". ${ }^{45}$

\subsubsection{THE PURPOSE OF A REASONABLE AUTHOR}

In the second, intermediate level of abstraction the interpreter disengages from the individuality of the constitution maker and turns to the imaginary figure of the reasonable person. He or she inquires into the purpose that the constitution maker would have envisioned, had they behaved as a reasonable person. Consequently, the interpreter replaces the specific author with the reasonable person. ${ }^{46}$ "The term 'reasonable person' takes us from the hypothetical intent of the individual author to the hypothetical intent of the ideal author who reflects the proper balance between the system's values and principles, as it exists for someone situated in the position of the real author". 47

The interpreter puts itself in the position of a reasonable author trying to understand the relevant constitutional provision in its 'natural environment'. This environment includes the immediate normative layout in which the provision in

\footnotetext{
42 Ibid., 150.

43 Ibid., 151.

44 Ibid., 161.

45 Ibid., 161.

46 Ibid., 151.

47 Ibid., 151.
} 
question operates. Hence, he or she "should aspire to harmony and integration with the other constitutional provisions. The individual constitutional provision being interpreted does not stand alone. It constitutes part of the broader constitutional layout. It influences the understanding of the constitution as a whole. The constitutional entirety, in turn, influences the meaning of the individual provision within it". 48

Judicial case law provides another important source of information about values and principles that help teach about the objective purpose of a constitutional text. According to Barak, "each judge is a link in a continuous chain of case law begun long before the era of the modern judge. Continuity, historical commitment, respect for the present and past, rational consideration of the legal tradition, and the need to guarantee security and certainty all justify judges' consulting case law-either as an option or as an obligation-as a source of information about the various levels of every text's objective purpose". ${ }^{49}$

\subsubsection{PURPOSE DERIVED FROM THE TYPE AND NATURE OF THE TEXT}

The third highest level of abstraction disengages not only from the individual constitution maker, but from the given constitution as well. The interpreter asks not what (objective) purpose ought $s /$ he attribute to the reasonable constitution maker, but rather what typical purpose characterizes a certain kind of constitution. S/he looks at the type and nature of the legal institutions in question. ${ }^{50}$

The interpreter draws inspiration for this level of abstraction from the ideas and concepts of the culture and legal tradition to which the given legal system belongs. Legal families are based on a common legal experience: "When expressions like 'void', 'authority', 'legal action', 'intent', 'public order', and similar key jurisprudential concepts appear in a normative text - particularly in a statute or constitution - they reflect a legal culture and legal tradition. These expressions are not empty vessels awaiting content. They reflect fundamental legal conceptions, derived from the legal 'family' (tradition) to which the system belongs and from the legal culture that gives these expressions their system-specific, culture-specific, and family-specific jurisprudential meaning". ${ }^{51}$

Another source close to this one is comparative law. It guides the text's latent interpretive potential: "It shows the interpreter what may and may not be accomplished through the text. It gives the judge information about the successes and failures of the different possibilities latent in the text. It makes the interpreter

\footnotetext{
48 Ibid., 159.

49 Ibid., 162.

50 Ibid., 152

51 Ibid., 162.
} 
aware of links between a solution to the interpretive problem he or she faces and other legal problems. Comparative law serves as an experienced friend". 52

Still, comparison has its limits. Barak rightly points out that "comparative law is not just about comparing laws. Comparative interpretation can take place only among legal systems that share a common ideological basis. An interpreter must be sensitive to the uniqueness of each legal system. Sometimes, comparison is impossible. When an interpreter is persuaded, however, that the social, historical, and religious circumstances create a common ideological base, he or she may use a foreign legal system to formulate the objective purpose of the text". 53 Nevertheless, the interpreters "should be careful not to let intellectual curiosity lead them to imitate at the cost of self-denial. The purpose of consulting comparative law is to understand the local text better. The comparison must not interfere with the normative harmony of local law". ${ }^{54}$

\subsubsection{PURPOSE DERIVED FROM THE SYSTEM'S FUNDAMENTAL} PRINCIPLES

The fourth and highest level of abstraction engages in the discovery of the objective purpose which can be derived from the fundamental values of the system. The interpreter consults the legal system's general values, from which he or she tries to deduce the constitution's objective purpose. ${ }^{55}$ Under Barak's theory of purposive interpretation, "fundamental values and conceptions surrounding the constitution constitute the objective purpose of the constitution itself. These are the nation's basic conceptions of its values and principles. They express society's basic positions about human rights, separation of powers, and democracy". ${ }^{56}$

It is not always easy to grasp fundamental principles. They vary from legal system to legal system and from era to era. More importantly, no constitution comes with an instruction booklet listing its basic values and principles. They are sprinkled throughout it, stated expressly or between the lines. According to Barak, there are generally three kinds of basic principles, which may overlap: "ethical principles (like justice, morality, fairness, good faith, human rights); societal objectives (like the preservation of the state and its democratic character, public peace and security, separation of powers, rule of law, judicial independence, consistency and harmony in law, certainty and security in interpersonal arrangements, realization of reasonable expectations, human rights); and patterns

\footnotetext{
52 Ibid., 170.

53 Ibid., 169-170.

54 Ibid. 170.

55 Ibid., 152.

56 Ibid., 153.
} 
of behavior (like reasonableness, fairness, good faith). The categories are fluid; human rights, for example, can be seen as both an ethical value and a societal goal". 57

\subsection{FORMULATING THE ULTIMATE PURPOSE}

Formulating an ultimate purpose is the decisive stage of the interpretative process. All previous stages of the discovery of the subjective or objective purpose of a constitution may diverge within it (horizontally) or from each other (vertically). Horizontal divergence occurs between two sets of data (subjective purpose) or principles and values (objective purpose) of the same status. Vertical divergence occurs between the data, principles and values of different statuses.

First, a proper relationship should be established between the subjective and objective purpose in formulating constitution's ultimate purpose. According to Barak, "the intent of the constitutional founders (abstract subjective intent) remains important. We need the past to understand present. [...] It is not however decisive. Its weight is substantial immediately following the founding, but as time elapses, its influence diminishes". ${ }^{58}$

Unlike a statute which regulates present rights and obligations, and is easily enacted and amended, a constitution is always drafted with an eye to the future. Its function is to provide a continuing framework for the exercise of governmental power and protection of human rights. ${ }^{59}$ For that reason, the purposive interpretation of constitutional texts favors objective purpose in constitutional interpretation.

Second, the internal relationship between various objective purposes should be clarified. The lines between different levels of abstraction of the objective purpose are sometimes fluid. Equally, there is no pre-established order for referring to various levels. Each interpreter may start with the level that appears most appropriate to him or her, so long as all the levels are evaluated. ${ }^{60}$ Accordingly, there is no hierarchy between different levels. Purposive interpretation seeks to achieve synthesis and integration in the context of different presumptions. ${ }^{61}$ Nevertheless, "every purposive presumption has a 'weight' that varies with the weight of the fundamental value from which the presumption is derived. The

\footnotetext{
57 Ibid., 165.

58 Ibid., 190-191.

59 Hunter v. Southam Inc [1984] 2 S.C.R. 145, 156; quoted in: ibid., 370-371.

60 Ibid., 150.

61 Ibid., 183.
} 
'heavier' a fundamental value, the heavier the purposive presumption derived from $i^{\prime \prime} .62$

\section{CONCLUSION}

Political jurisprudence rightly points out that judges, and especially constitutional court judges, sometimes act like political actors, and that their decisions are a function of strategic and ideological considerations as much as legal ones. As a result, the proper role of the courts, notably in exercising their review of constitutionality, which allows them a particularly high degree of discretion, has been one of the most debated issues in the modern political and legal theory.

One aspect of that debate concerns how to evaluate the extent of interpretative fidelity of judges to constitutional texts, and thus the level of their political engagement. Democracy and the rule of law are just some of the reasons why individuals, academics and public opinion should have a yardstick in that process.

Aharon Barak's Purposive Interpretation in Law offers some heuristic tools in that respect. It argues that the aim of every interpretation should be to actualize the purpose that the constitution was designed to achieve. With that goal in mind, Barak develops a theory directed at establishing subjective and objective purposes in interpreting constitutions, and the resolution of their potential conflicts.

While it does not underestimate the importance of the intent of the constitution maker (subjective purpose), the theory of purposive interpretation in law favors objective purpose in constitutional interpretation. It takes into account that constitutions are not easily enacted and amended, and that they are necessarily always drafted with an eye to the future - to provide a continuing framework for the exercise of governmental power and protection of human rights. Thus, the objective purpose of a constitutional text emerges through an interpretative juxtaposition of various levels of abstraction which include: author's hypothetical intent; purpose of a reasonable author; purpose derived from the type and nature of the text; and purpose derived from the system's fundamental principles.

\section{BIBLIOGRAPHY}

1. Barak, Aharon. Purposive Interpretation in Law. Trans. Sari Bashi. Princeton and Oxford: Princeton University Press, 2005.

62 Ibid., 175. 
2. Brigham, John. "Judicial Review": 536-542. In: Kermit L. Hall, James W. Ely, Jr., and Joel B. Grossman, eds. The Oxford Companion to the Supreme Court of the United States. Oxford \& New York: Oxford University Press, 2005.

3. Brubaker, Stanley C. "Judicial Self-Restraint": 542-544. In: Kermit L. Hall, James W. Ely, Jr., and Joel B. Grossman, eds. The Oxford Companion to the Supreme Court of the United States. Oxford \& New York: Oxford University Press, 2005.

4. Dorsen, Norman, Michel Rosenfeld, Andras Sajo, and Susanne Baer. Comparative Constitutionalism - Cases and Materials. St. Paul, MN: Thomson West, 2003.

5. Eisenmann, Charles. "La justice dans I'Etat": 158-168. In: Charles Leben, ed. Charles Eisenmann, Ecrits de théorie du droit, de droit constitutionnel et d'idées politiques. Paris: Edition Panthéon-Assas, 2002.

6. Fromont, Michel. La justice constitutionnelle dans le monde. Paris: Dalloz, 1996.

7. Gibson, James L. "Judicial Institutions": 514-534. In: R. A. W. Rhodes, Sarah A. Binder, and Bert A. Rockman, eds. The Oxford Handbook of Political Institutions. Oxford and New York: Oxford University Press, 2008.

8. Goldsworthy, Jeffrey. "Conclusions": 321-345. In: Jeffrey Goldsworthy, ed. Interpreting Constitutions - A comparative Study. Oxford and New York: Oxford University Press, 2006.

9. Jeffrey Goldsworthy, ed. Interpreting Constitutions - A comparative Study. Oxford and New York: Oxford University Press, 2006.

10. Kommers, Donald P. "Germany: Balancing Rights and Duties": 161-214. In: Jeffrey Goldsworthy, ed. Interpreting Constitutions - A comparative Study. Oxford and New York: Oxford University Press, 2006.

11. Loewenstein, Karl. Political Power and the Governmental Process. Chicago: The University of Chicago Press, 1957.

12. Montesquieu. De l'Esprit des lois. I. Paris: Gallimard, 1995.

13. Sadurski, Wojcicech. Rights Before Courts - A Study of Constitutional Courts in Postcommunist States of Central and Eastern Europe. Dordrecht: Springer, 2005.

14. Shapiro, Martin, and Alec Stone Sweet. On Law, Politics and Judicialization. Oxford and New York: Oxford University Press, 2002.

15. Shapiro, Martin. Freedom of Speech: The Supreme Court and Judicial Review. Englewood Cliffs, New Jersey: Prentice-Hall, Inc., 1966.

16. Smilov, Daniel. "The Character and Legitimacy of Constitutional Review: Eastern European Perspectives. A Review of: Wojciech Sadurski, ed., 
Constitutional Justice, East and West: Democratic Legitimacy and Constitutional Courts in Post-Comunist Europe in a Comparative Perspective (Kluwer Law International, The Hague-London-New York: 2003), 450 pp.; Radoslav Prochazka, Mission Accomplished: On Founding Constitutional Adjudication in Central Europe (Central European Univ. Press, Budapest - New York: 2002), 358 pp." International Journal of Constitutional Law 1 (2004): 177-194.

17. Stone Sweet, Alec. "The Politics of constitutional review in France and Europe." International Journal of Constitutional Law 1 (2007): 69-91.

18. Tushnet, Mark. "The United States: Eclecticism in the Service of Pragmatism": 7-54. In: Jeffrey Goldsworthy, ed. Interpreting Constitutions - A comparative Study. Oxford and New York: Oxford University Press, 2006.

19. Whittington, Keith E., R. Daniel Kelemen, and Gregory A. Caldeira, eds. The Oxford Handbook of Law and Politics. Oxford and New York: Oxford University Press, 2010.

20. Wiecek, William M. Liberty under Law - The Supreme Court in American Life. Baltimore and London: The Johns Hopkins University Press, 1990. 